\title{
Decrease in IGF-I Binding Sites on Human Promyelocytic Leukemia Cell Line (HL-60) with Differentiation
}

\author{
IzUmi SUKEGAWA, Naomi HIZUKA, KazUe TAKANO, \\ KUMIKo ASAKAWA and KaZUo SHIZUME
}

\author{
Department of Medicine \\ Institute of Clinical Endocrinology \\ Tokyo Women's Medical College \\ Tokyo, 162, Japan
}

\begin{abstract}
Specific insulin-like growth factor I (IGF-I) receptors on human promyelocytic leukemia cell line (HL-60) were identified and characterized. [ ${ }^{125}$ I]IGF-I specifically bound to the cells, and $\left.{ }^{125} \mathrm{I}\right] \mathrm{IGF}-\mathrm{I}$ binding to the cells was displaced by unlabeled IGF-I in a dose dependent manner. [ ${ }^{125}$ I]IGF-I binding to the cells were displaced by multiplication stimulating activity (MSA) and porcine insulin, with potencies that were 10 and 100 times less than that of IGF-I, respectively. By an affinity labeling technique, IGF type I receptors were found to be present on the HL-60 cells.

After the cells were differentiated to the macrophage-like cells by 12-o-tetra-decanoyl-phorbol-13-acetate (TPA) and 1,25-dihydroxy-vitamin $\mathrm{D}_{3}$ $\left(1,25(\mathrm{OH})_{2} \mathbf{D}_{3}\right)$, [ ${ }^{125}$ I]IGF-I binding to the cells decreased significantly. By Scatchard analysis, it was found to be due to a decrease in the number of IGF-I receptors.

Thus, the differentiation of HL-60 cells to the macrophage-like cells was accompanied by a decrease in IGF-I receptors.
\end{abstract}

The HL-60 cells can be selectively induced to mature to granulocytes or macrophage-like cells by culture with a number of reagents; i.e. the differentiation to granulocyte is induced by retinoic acid (Reiss et al., 1985), butyric acid (Fischkoff and Con-

\footnotetext{
Received August 6, 1986

Please address all correspondence to:

Dr. Izumi Sukegawa

Department of Medicine

Institute of Clinical Endocrinology

Tokyo Women's Medical College

8-1 Kawada-cho Shinjuku-ku

Tokyo, 162, Japan
}

don, 1985) and dimethyl sulfoxide (DMSO) (Collins et al., 1978), and the differentiation to macrophage is induced by phorbol esters (Rovera, 1979) and vitamin $\mathrm{D}_{3}$ (Reitsma et al., 1983).

The number of transferrin receptors (Yeh et al., 1982) and $\beta$-adrenergic receptors (Hoshino et al., 1986) on HL-60 cells increased with differentiation. Yamanouchi et al. (1982) reported that differentiation of HL-60 cells into granulocytes or macrophage-like cells was accompanied by an increase in the number of insulin receptors. Specific receptors for insulin and IGF-I were 
located in a variety of cells and both receptors coexist in most cells (Nissley and Rechler, 1984).

In the present study, we investigated IGF-I receptors on the HL-60 cells and the change in IGF-I receptor sites with the differentiation to macrophage-like cells.

\section{Materials and Methods}

\section{Hormones and reagents}

IGF-I was kindly provided by Fujisawa Pharmaceutical Co. (Osaka). The IGF-I preparation was synthesized by recombinant DNA technology as described (Niwa et al., 1986), and the amino acid sequence of the preparation is the same as that of natural IGF-I. Crystalline porcine insulin and MSA were gifts from Eli Lilly Co. (Indianapolis, IN) and from Dr. M. Kasuga, the University of Tokyo (originally obtained from Dr. M. P. Czech (Worcester, MA)), respectively. $\mathrm{Na}^{125} \mathrm{I}$ was purchased from New England Nuclear (Boston, MA). Both $\left[{ }^{125} \mathrm{I}\right] \mathrm{IGF}-\mathrm{I}$ and $\left[{ }^{125} \mathrm{I}\right]$ insulin were prepared by the chloramine-T method modified as reported (Zapf et al., 1975; Roth, $1975)$ with a specific activity of $180 \mu \mathrm{Ci} / \mu \mathrm{g}$ and $100 \mu \mathrm{Ci} / \mu \mathrm{g}$, respectively. TPA was purchased from Sigma Chemicals (St Louis, MO), and $1,25(\mathrm{OH})_{2} \mathrm{D}_{3}$ was kindly provided by Chugai Pharmaceuticals (Tokyo). Disuccinimidyl suberate (DSS) was purchased from Pierce Chemical Co. (Rockford, IL).

\section{Cells and cell differentiation}

Cultured HL-60 cells were provided by Dr. T. Yamanouchi of the University of Tokyo. The cells were grown at $37^{\circ} \mathrm{C}$ in RPMI-1640 medium (GIBCO, Grand Island, NY), containing 10\% fetal calf serum (FCS) and under $5 \% \mathrm{CO}_{2}$ atmosphere. TPA dissolved in acetone or $1,25(\mathrm{OH})_{2} \mathrm{D}_{3}$ dissolved in ethanol was added to the cell suspension at a final concentration of $10 \mathrm{ng} / \mathrm{ml}$ or $2.0 \times 10^{-9} \mathrm{M}$, respectively. Control cultures contained equivalent amounts of the solvents. Cytospan slide preparations of $0.1 \mathrm{ml}$ aliquots of suspension were prepared using a Shandon-Elliot Cytospin centrifuge (model SCA0031, Cheshire, England), and the cells were stained with May-Grünwald-Giemza.

\section{Binding studies for IGF-I and insulin}

The HL-60 cells were allowed to grow to a concentration of $5 \times 10^{5}$ cells $/ \mathrm{ml}$ in culture flasks and centrifuged at $400 \times \mathrm{g}$ for $5 \mathrm{~min}$. The cells were resuspended in RPMI-1640 medium containing $10 \%$ FCS, and then the cells were cultured for $24 \mathrm{~h}$ or $48 \mathrm{~h}$ in the presence or absence of TPA or $1,25(\mathrm{OH})_{2} \mathrm{D}_{3}$, respectively. At the end of the incubation, the cells were washed once with assay buffer (50 mM N-2-hydroxyethylpiperazine-N'-2-ethanesulfonic acid (HEPES) lymphocyte buffer with $1 \%$ bovine serum albumin (BSA)), and suspended in the same buffer. The cells $\left(1 \times 10^{7}\right.$ cells $\left./ \mathrm{ml}\right)$ were incubated with $\left[{ }^{125} \mathrm{I}\right]$ IGF-I in the presence or absence of IGF-I in a total volume of $0.5 \mathrm{ml}$. The cell viability examined by the trypan blue exclusion method was greater than $95 \%$ in the assay buffer for $48 \mathrm{~h}$. At the end of the incubation, replicate $200 \mu \mathrm{l}$ aliquots were layered onto ice-cold buffer and centrifuged for $8000 \times \mathrm{g}$ in a Beckman B Microfuge (Beckman, Palo Alto, CA). After aspiration of the supernatant, the cell-associated radioactivity was counted. Nonspecific binding was defined as cell-associated radioactivity in the presence of an excess of unlabeled IGF-I $(1 \mu \mathrm{g} / \mathrm{ml})$. Specific binding is the difference between total binding and nonspecific binding. The binding study for porcine insulin was carried out similarly to that for IGF-I.

\section{Cross-linking of $\left[{ }^{125} I\right] I G F-I$ to $H L-60$ cells}

The HL-60 cells, $5 \times 10^{6}$ cells $/ \mathrm{ml}$, were incubated in $50 \mathrm{mM}$ HEPES lymphocyte buffer with $0.1 \% \mathrm{BSA}$ at $4{ }^{\circ} \mathrm{C}$ overnight with $\left[{ }^{125} \mathrm{I}\right] \mathrm{IGF}-\mathrm{I}$ in the presence or absence of unlabeled IGF-I $(1 \mu \mathrm{g} / \mathrm{ml})$. The cells were washed in ice-cold buffer without albumin and resuspended in the same buffer. DSS, dissolved in DMSO, was added at a final concentration of $1 \mathrm{mM}$. After $30 \mathrm{~min}$, the reaction was stopped by $10 \mathrm{mM}$ Tris-(hydroxymethyl) aminomethane and $1 \mathrm{mM}$ EDTA. The cells were solubilized in $50 \mathrm{mM}$ HEPES buffer containing $1 \%$ Triton X-100, $0.15 \mathrm{M} \mathrm{NaCl}$ and $2 \mathrm{mM}$ phenylmethylsulfonyl fluoride for one hour at $4{ }^{\circ} \mathrm{C}$ and centrifuged at $100,000 \times \mathrm{g}$ for $45 \mathrm{~min}$. The supernatant was precipitated with ice-cold $10 \%$ trichloroacetic acid and the pellet was boiled for $5 \mathrm{~min}$ in $2 \%$ sodium dodecyl sulfate (SDS), $10 \%$ (v/v) glycerol, $0.5 \mathrm{M}$ 2-mercaptoethanol, $0.01 \%$ bromophenol blue and $10 \mathrm{mM}$ sodium phosphate buffer, $\mathrm{pH}$ 7.0. Samples were analyzed on $0.1 \%$ SDS $/ 7.5 \%$ polyacrylamide gel electrophoresis according to 
Laemmli (1970). Autoradiography was carried out using Kodak X-Omat film with an intensifying screen.

\section{Results}

Binding of $\left[{ }^{125} I\right] I G F-I$ to the HL-60 cells

[125I]IGF-I specifically bound to the HL60 cells, and the binding increased as a function of the cell concentration. The binding of $\left[{ }^{125} \mathrm{I}\right] \mathrm{IGF}-\mathrm{I}$ to the cells was time and temperature dependent (Fig. 1). At $37^{\circ} \mathrm{C}$, the maximal binding which occurred at $30 \mathrm{~min}$ was greater than that at $15^{\circ} \mathrm{C}$ and $4^{\circ} \mathrm{C}$, but declined rapidly and the condition was too unstable for the binding study. At $15^{\circ} \mathrm{C}$, there was a slower association of $\left[{ }^{125} \mathrm{I}\right] \mathrm{IGF}-\mathrm{I}$ with the cells, and the maximal binding occurring at $2 \mathrm{~h}$. At $4^{\circ} \mathrm{C}$, the binding reached a plateau by $18 \mathrm{~h}$, and the maximal binding was the same as that at $15^{\circ} \mathrm{C}$. From these data, the binding studies were performed at $15^{\circ} \mathrm{C}$ for $2 \mathrm{~h}$. At a cell concentration of $1 \times 10^{7}$ cells $/ \mathrm{ml}$, the specific binding of [ $\left.{ }^{125} \mathrm{I}\right] \mathrm{IGF}-\mathrm{I}$ averaged $8 \%$.
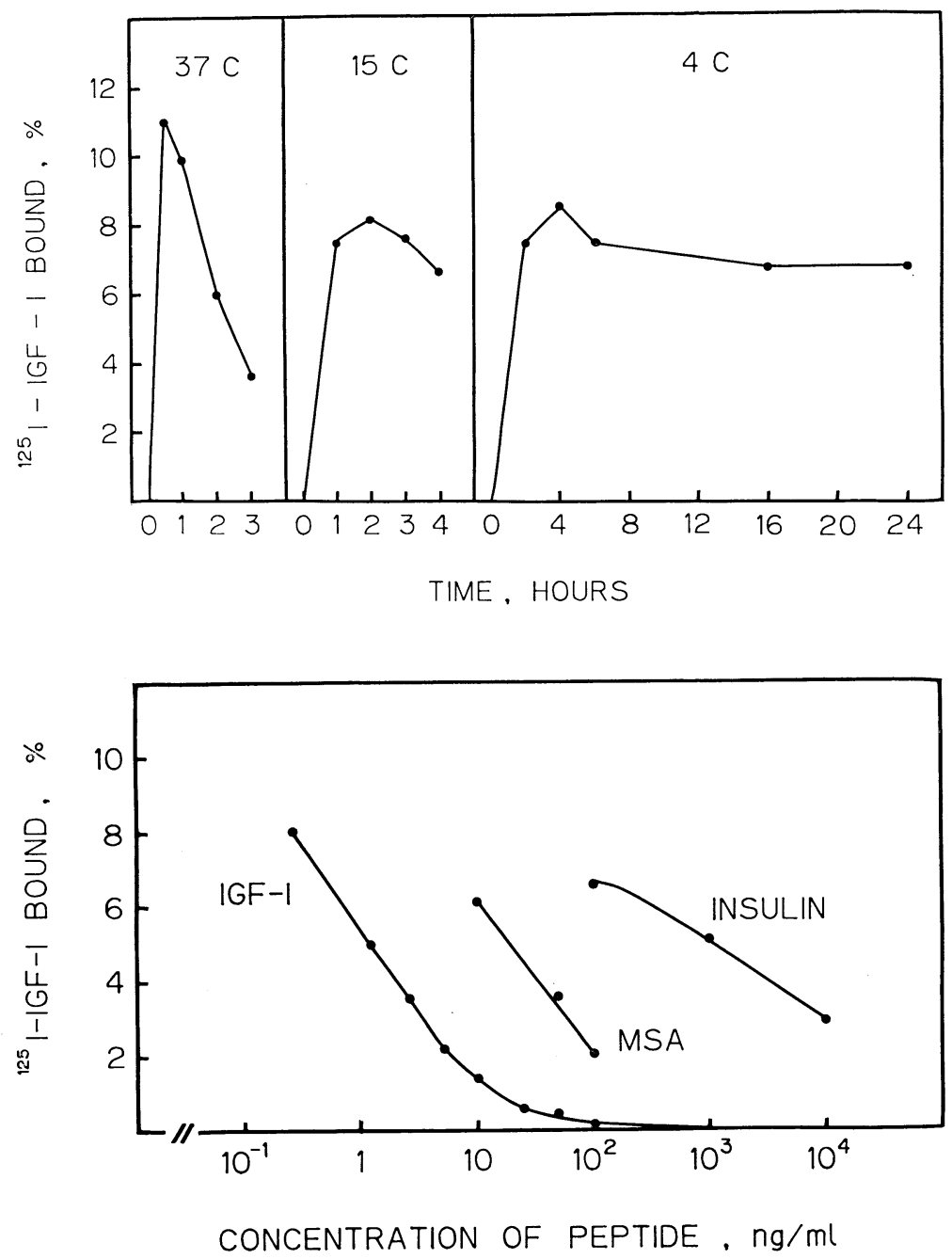

Fig. 1. Effect of time and temperature on specific [ $\left.{ }^{125} \mathrm{I}\right]$ IGF-I binding to the HL-60 cells. The cells $\left(5 \times 10^{6}\right.$ cells $\left./ \mathrm{ml}\right)$ were incubated at $37^{\circ} \mathrm{C}, 15^{\circ} \mathrm{C}$ and $4^{\circ} \mathrm{C}$ for varying times.

Fig. 2. Competition for specific $\left[{ }^{125}\right.$ I] IGF-I binding to the HL-60 cells $\left(8 \times 10^{6} \mathrm{cells} / \mathrm{ml}\right)$ by IGFI, MSA and porcine insulin. 
The nonspecific binding was less than $2 \%$.

\section{Specificity of IGF-I receptor}

[ ${ }^{125}$ I]IGF-I binding to the HL-60 cells was displaced by unlabeled IGF-I in a dose dependent manner (Fig. 2). A 50\% inhibition of [ $\left.{ }^{125} \mathrm{I}\right] \mathrm{IGF}-\mathrm{I}$ binding was obtained at a concentration of $2 \mathrm{ng} / \mathrm{ml}$ IGF-I. The binding of $\left.{ }^{125} \mathrm{I}\right] \mathrm{IGF}-\mathrm{I}$ to the cells was displaced by MSA and porcine insulin, with potencies 10 and 100 times less than that of IGF-I, respectively (Fig. 2). In addition, $\left[{ }^{125} \mathrm{I}\right]$ insulin specifically bound to the cells, and IGF-I inhibited insulin binding with a potency at least 100 times lower than that of insulin (data not shown). When the HL-60 cells were cross-linked to [ ${ }^{125}$ I]IGF-I with DSS, solubilized and electrophoresed in the presence of reductant, the major band migrated at $\mathrm{Mr}=130,000$. An excess of unlabeled IGF-I blocked the formation of this band (Fig. 3).

Changes in morphology of HL-60 cells induced by reagents

The morphological changes induced by TPA in the HL-60 cells are illustrated in Fig. 4. When untreated, HL-60 cells were predominantly typical promyelocytes with large round nuclei, basophilic cytoplasm with azurophilic granules, and the nuclear/ cytoplasmic $(\mathrm{N} / \mathrm{C})$ ratio was relatively high. The addition of TPA at a final concentration of $10 \mathrm{ng} / \mathrm{ml}$ to the culture for $24 \mathrm{~h}$ induced striking morphological differentiation of monocyte or macrophage-like cells in the majority of the cells. The morphological changes in the cells were dramatical; the azurophilic granules disappeared and the N/C ratio became small. Furthermore, the cell changed similarly to that of TPA and the most striking change was observed at $48 \mathrm{~h}$ incubation with $1,25(\mathrm{OH})_{2} \mathrm{D}_{3}$.

\section{Changes in IGF-I receptors with cell differ- entiation}

Fig. 5 shows [ $\left.{ }^{125} \mathrm{I}\right]$ IGF-I binding to the

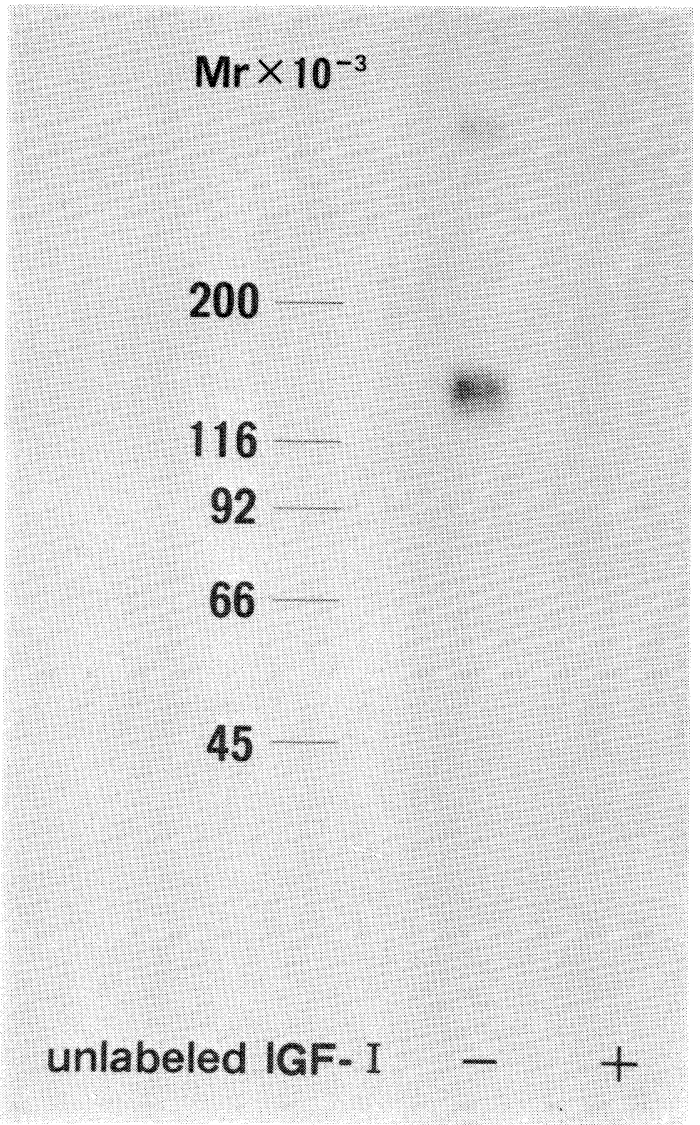

Fig. 3. Cross-linking of $\left[{ }^{125} I\right] I G F-I$ to the HL60 cells. Left lane: unlabeled IGF-I (-), Right lane : unlabeled IGF-I $(+)$.

HL-60 cells after incubation with or without TPA. After treatment with TPA for $24 \mathrm{~h}$, the specific binding of [125I]IGF-I to the HL-60 cells was decreased to $67.4 \pm 16.5 \%$ (mean \pm SEM, $n=3$ ) of that of untreated cells. The Scatchard analysis of the binding revealed a curvilinear pattern and the cause of the decrease in [ ${ }^{125}$ I]IGF-I binding to the treated cells was primarily a decrease in the number of IGF-I binding sites but not to a change in affinity. Assuming the existence of two classes of binding sites, the number of IGF-I receptors for high affinity sites decreased from $3,500 /$ cell to $2,300 /$ cell. The affinity constant (Ka) for the TPA 


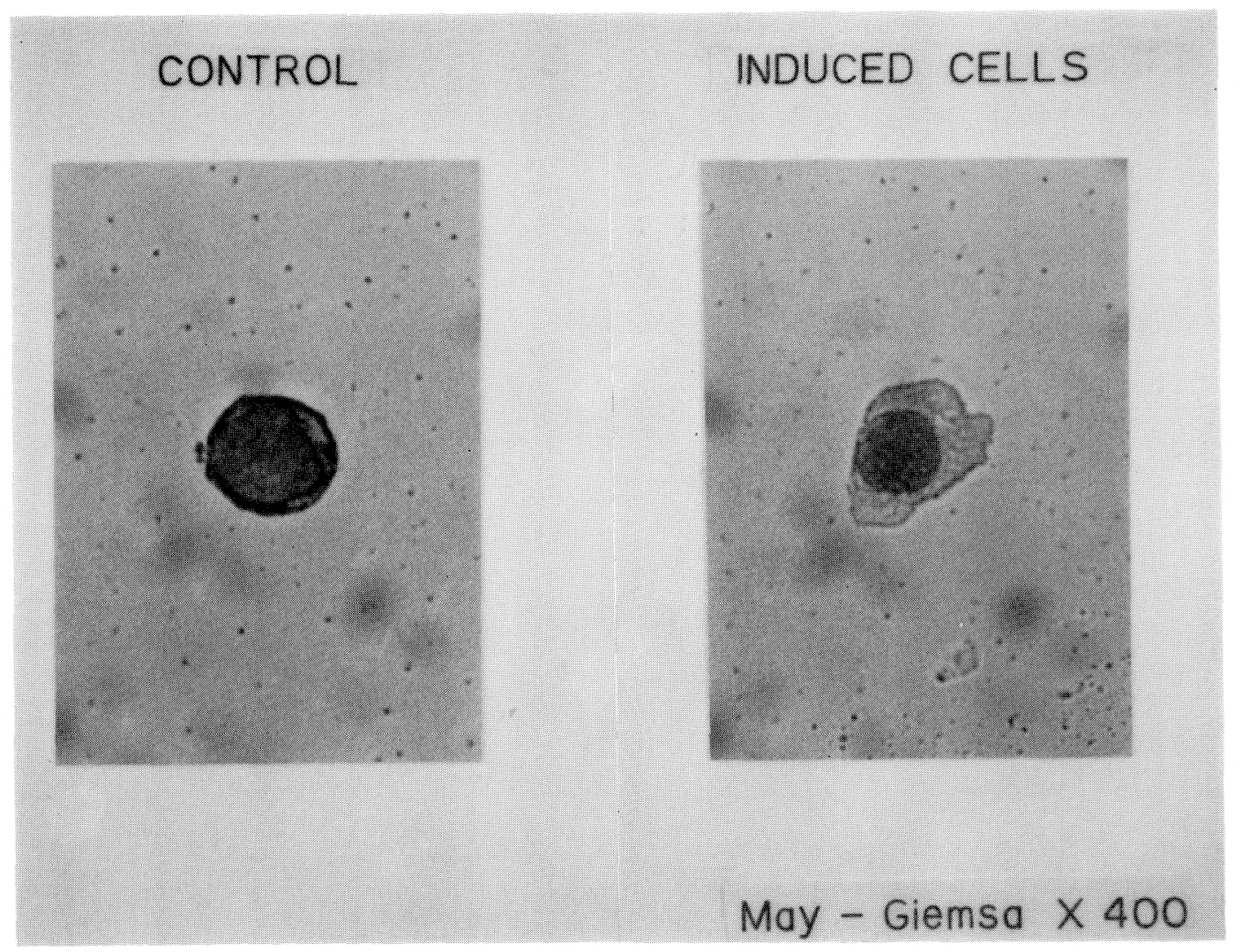

Fig. 4. Morphological changes induced in HL-60 cells. Cytospan preparation cells cultured with or without TPA. Left side: untreated cells $(\times 400)$. Right side : treated with TPA, $10 \mathrm{ng} / \mathrm{ml}$, for $24 \mathrm{~h}(\times 400)$.

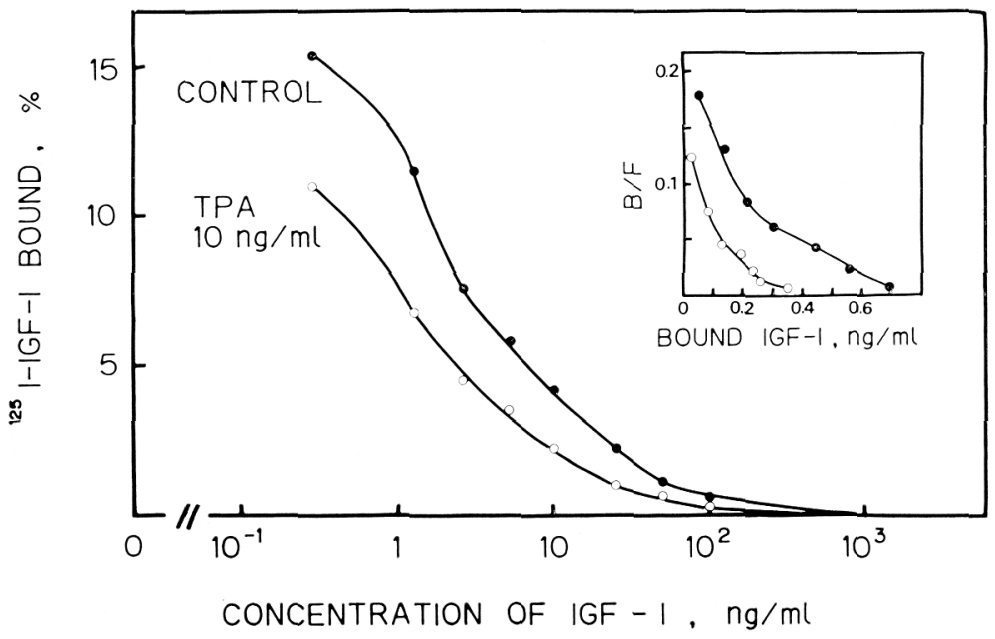

Fig. 5. IGF-I binding to the HL-60 cells $\left(9.1 \times 10^{6}\right.$ cells $/ \mathrm{ml}$ ) treated with TPA. HL-60 cells were cultured with $(\bigcirc)$ or without (O) $10 \mathrm{ng} / \mathrm{ml}$ TPA for $24 \mathrm{~h}$ at $37^{\circ} \mathrm{C}$. At the end of the incubation, the cells were washed as described in the Materials and Methods and then $\left[{ }^{125} \mathrm{I}\right]$ IGF-I binding to the cells was determined. Inset: Scatchard plot for the binding of $\left[{ }^{125} \mathrm{I}\right] \mathrm{IGF}-\mathrm{I}$ to the cells. Results of a single representative experiment are shown. 


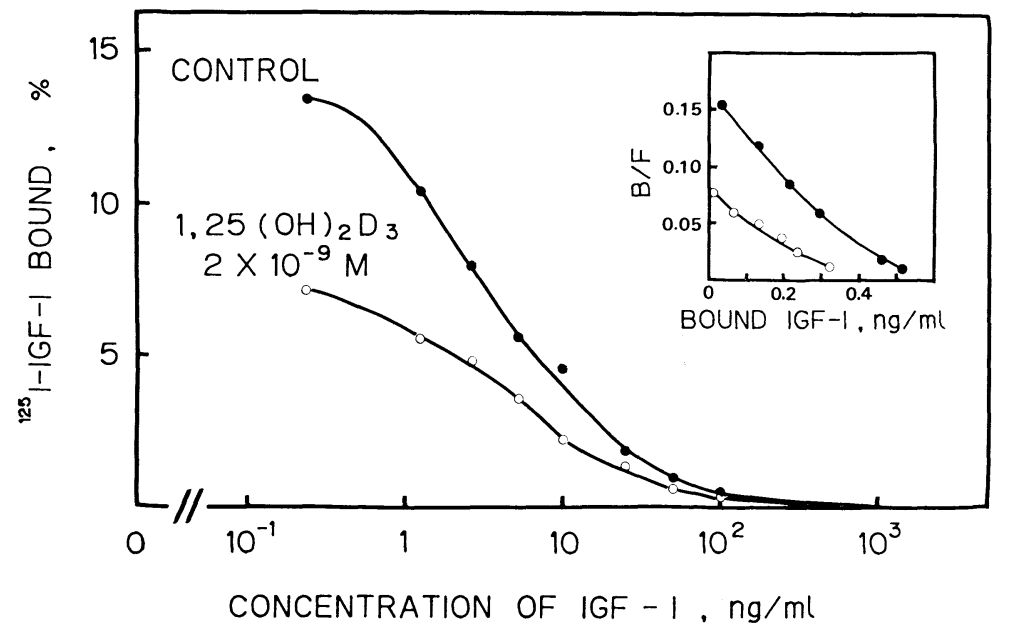

June 1987

Fig. 6. IGF-I binding to the HL-60 cells $\left(8.1 \times 10^{6}\right.$ cells $/ \mathrm{ml}$ ) treated with $1,25(\mathrm{OH})_{2} \mathrm{D}_{3}$. The HL-60 cells were incubated with (○) or without $(O) 2 \times$ $10^{-9} \mathrm{M} \quad 1,25(\mathrm{OH})_{2} \mathrm{D}_{3}$ for $48 \mathrm{~h}$. Then the binding studies were carried out similarly to those described in Fig. 5. Results of a single representative experiment are shown. treated cells was similar to that for untreated cells $\left(\mathrm{Ka}=3.36 \times 10^{9} \mathrm{M}^{-1}\right.$ vs. $\mathrm{Ka}=$ $\left.3.51 \times 10^{9} \mathrm{M}^{-1}\right)$.

When the HL-60 cells were incubated with $1,25(\mathrm{OH})_{2} \mathrm{D}_{3}$ at a final concentration $2.0 \times 10^{-9} \mathrm{M}$ for $48 \mathrm{~h}$, the specific binding of the [125I]IGF-I to the cells was $64.1 \pm$ $12.1 \%$ (mean $\pm \mathrm{SEM}, \mathrm{n}=3$ ) of that of before treatment (Fig. 6). The number of binding sites decreased similarly to that of TPA.

\section{Discussion}

In the present study, specific IGF-I receptors on the HL-60 cells were identified and characterized. [ $\left.{ }^{125} \mathrm{I}\right] \mathrm{IGF}-\mathrm{I}$ specifically bound to the HL-60 cells and the binding characteristics are similar to those demonstrated in the other cells. Compared to IGF-I, the relative potencies of MSA and porcine insulin in displacing the [ ${ }^{125}$ I]IGF-I binding were 10 and $1 \%$, respectively. In addition, IGF-I displaced [ ${ }^{125}$ I] insulin binding to HL-60 cells with a potency that was 100 times lower than that of insulin. These results show that HL-60 cells have specific receptors for IGF-I as well as for insulin. The IGF-I binding subunit was $\mathrm{Mr}=130,000$ by an affinity labeling technique. These data indicate that an IGF type I receptor is present on the HL-60 cells.

It has been reported that some reagents such as $1,25(\mathrm{OH})_{2} \mathrm{D}_{3}$, TPA, retinoic acid and DMSO increased insulin binding sites in a dose dependent manner and the increase was due to an increase in the number of insulin binding sites along with the differentiation to granulocytes or macrophage-like cells (Yamanouchi et al., 1982). In contrast to the insulin receptors on HL-60 cells, we observed that the [ ${ }^{125}$ I]IGF-I binding to the cells differentiated to macrophage-like cells by TPA or $1,25(\mathrm{OH})_{2} \mathrm{D}_{3}$ declined to 67 or $64 \%$ of the control, respectively. The Scatchard analysis showed that diminution of the specific binding with the differentiation was due to the decrease in the number of IGF-I binding sites, but not to the change in affinity. The decrease in [ ${ }^{125}$ I]IGF-I binding to the HL-60 cells treated with TPA or $1,25(\mathrm{OH})_{2} \mathrm{D}_{3}$ might be due to the presence of these reagents themselves. However, [125I]IGF-I binding to the cells treated with TPA or $1,25(\mathrm{OH})_{2} \mathrm{D}_{3}$ for 1 hour did not differ from the binding to untreated cells (data not shown). Therefore, the decrease in the binding to the treated cells may be due to the cell differentiation.

We observed that IGF-I and insulin 
binding sites of the erythroleukemia cell line, K-562, decreased with differentiation to mature erythrocytes (Hizuka et al., 1987), suggesting that both IGF-I and insulin receptors might be regulated by the same mechanism. On HL-60 cells, however, IGF-I and insulin receptors seem to be regulated by different mechanisms with cell differentiation. Shimizu and Roth (1985) reported that the TAl preadipocytes had low numbers of insulin receptors and poor sensitivity to insulin, whereas the TAl adipocytes had high numbers of receptors and good sensitivity to insulin. In contrast to insulin receptors, the preadipocytes had high numbers of receptors for IGF-I. They suggested that IGFs plays an important part in cell differentiation, especially immature stages. Our results agreed with their suggestion.

\section{Acknowledgements}

The authors are greatly indebted to Drs. T. Motoji and H. Mizoguchi for their helpful comments on the cell morphology and to Fujisawa Pharmaceutical Co. for kindly supplying biosynthetic IGF-I.

This work was partly supported by Grants in Aid Nos. 60770924, 58571012 and 58440084, for Scientific Research from the Ministry of Education, Science and Culture, Japan, a Research Grant from the intractable Diseasos Division, Public Health Bureau, Ministry of Health and Welfare, and a Research Grant from the Foundation for Growth Science in Japan.

\section{References}

Collins, S. J., F. W. Ruscetti, R. E. Gallagher and R. C. Gallo (1978). Terminal differentiation of human promyelocytic leukemia cells induced by dimethyl sulfoxide and other polar compounds. Proc. Natl. Acad. Sci. 75, 24582462.

Fischkoff, S. A. and M. E. Condon (1985). Switch in differentiative response to maturation inducers of human promyelocytic leukemia cells by prior exposure to alkaline conditions. Can. Res. 45, 2065-2069.

Hizuka, N., I. Sukegawa, K. Takano, K. Asakawa, R. Horikawa, T. Tsushima and K. Shizume (1987). Characterization of insulin-like growth factor I receptors on human erythroleukemia cell line (K-562 cells). Endocrinol. Japon. 34, 81-88.

Hoshino, S., K. Oshimi and H. Mizoguchi (1986). The change in $\beta$-adrenergic receptors on differentiation of HL-60 cells. Igaku no ayumi 137, 637-638 (in Japanese).

Laemmli, U. K. (1970). Cleavage of structural protein during the assembly of the head of bacteriophage T4. Nature 227, 680-685.

Nissley, S. P. and M. M. Rechler (1984). Insulin-like growth factors: biosynthesis, receptors, and carrier proteins. In: Hormonal proteins and peptides. (C. H. Li ed.), Academic press, Orland. pp. 128-203.

Niwa, M., S. Sato, Y. Saito, F. Uchiyama, H. Ono, M. Yamashita, T. Kitaguchi, Y. Shiga, J. Notani, H. Yamada, Y. Ishii, I. Ueda and Y. Takagi (1986). Chemical synthesis, cloning and expression of genes for human somatomedin C (insulin-like growth factor I) and ${ }^{59}$ Val-somatomedin C. Annals of the New York Academy of Science, 469, 31-52.

Reiss, M., C. A. Maniglia and A. C. Sartorelli (1985). Reversible effects of retinoic acid on glycosaminoglycan synthesis during differentiation of HL-60 leukemia cells. Can. Res. 45, 2092-2097.

Reitsma, P. H., P. G. Rothberg, S. M. Astrin, J. Trial, Z. Bar-Shavit, A. Hall, S. L. Teitelbaum and A. J. Kahn (1983). Regulation of $m y c$ gene expression in HL-60 leukaemia cells by a vitamin D metabolite. Nature $306,492-$ 494.

Roth, J. (1975). Methods for assaying immunologic and biologic properties of iodinated peptide hormones. Methods Enzym. 37, 223233.

Rovera, G., T. G. O'Brien and L. Diamond (1979). Induction of differentiation in human promyelocytic leukemia cells by tumor promoters. Science 204, 868-870.

Shimizu, M. and R. A. Roth (1985). Characterization of the insulin and insulin-like growth factor receptors and responsitivity of a fibroblasts/adipocyte cell line before and after differentiation. 67th Annual meeting of The Endocrine Society, Abst. \#804. 
Yamanouchi, T., T. Tsushima, H. Murakami, Y. Sato, K. Shizume, K. Oshimi and H. Mizoguchi (1982). Differentiation of human promyelocytic leukemia cells is accompanied by an increase in insulin receptors. Biochem. Biophys. Res. Commun. 108, 414-420.

Yeh, C. G., M. Papamichael and W. P. Faulk (1982). Loss of transferrin receptors following induced differentiation of HL-60 promyelocytic leukemia cells. Exp. Cell. Res. 138, 429-433.

Zapf, J., M. Mader, M. Waldvogel, D. S. Schalch and E. R. Froesch (1975). Specific binding of nonsuppressible insulinlike activity to chicken embryo fibroblasts and solubilized fibroblast receptor. Arch. Biochem. Biophys. 168, 630637. 